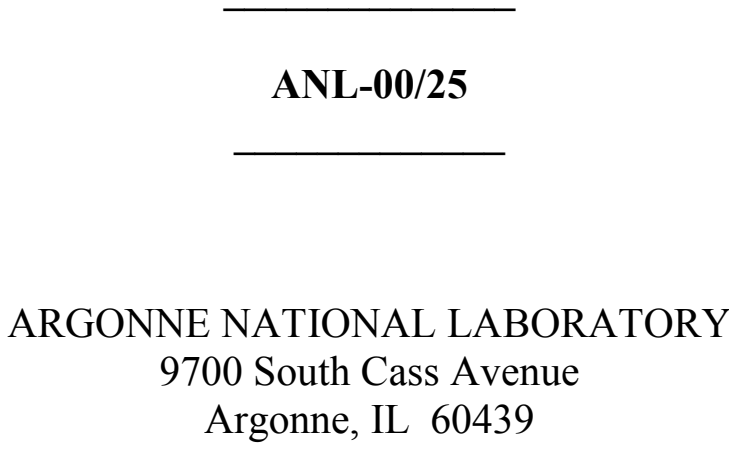

\title{
TRANSFORMATION OF UREX EFFLUENTS TO SOLID OXIDES BY CONCENTRATION, DENITRATION, AND CALCINATION
}

by

George F. Vandegrift

Chemical Technology Division

December 2000 


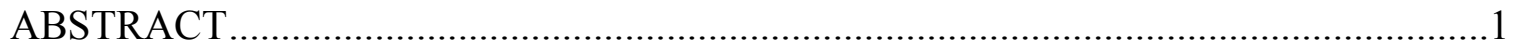

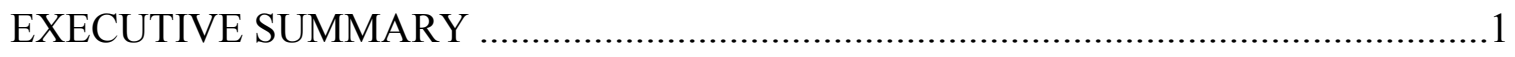

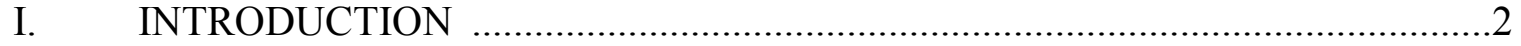

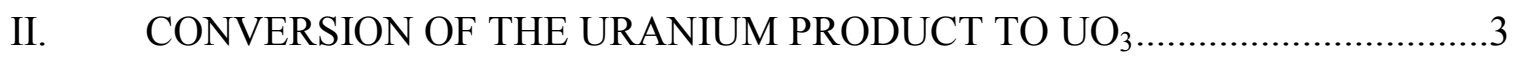

III. CONVERSION OF THE UREX RAFFINATE TO SOLID OXIDES ................4

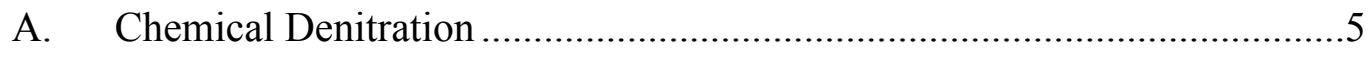

1. Chemistry of Denitration by $\mathrm{HCO}_{2} \mathrm{H}$ and $\mathrm{HCHO}$..........................6

2. Industrial Denitration of Radioactive Waste ...................................9

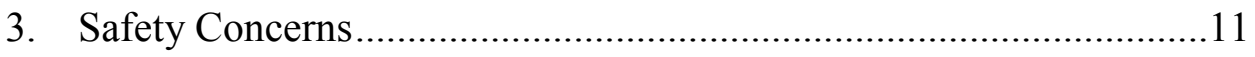

B. Fluidized Bed Calcination of the UREX Raffinate ...............................12

IV. CONCLUSION AND TECHNICAL NEEDS.............................................13

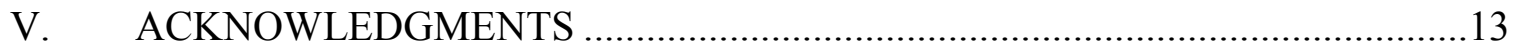

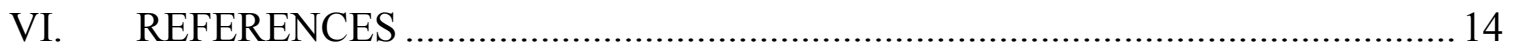




\section{LIST OF TABLES}

No. $\underline{\text { Title }}$

$\underline{\text { Page }}$

1. Major-Constituent Composition of Process Streams for Batch Generation

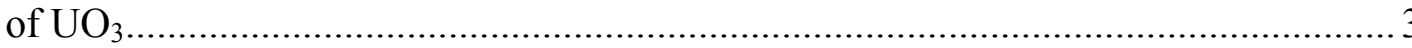

2. Reactions of Nitric Acid with Formic Acid under Various Conditions.......................

3. Reactions of Nitric Acid with Formaldehyde under Various Conditions.................... 7

4. Effects of Operating Conditions on the Composition of the NitrogenOxide-Containing Off-gas for the Reaction between a Solution of Nitric acid and Sodium Nitrate with either Formic Acid or Formaldehyde. 


\title{
TRANSFORMATION OF UREX EFFLUENTS TO SOLID OXIDES BY CONCENTRATION, DENITRATION, AND CALCINATION
}

\author{
by
}

George F. Vandegrift

\begin{abstract}
A literature survey was conducted on the potential means for converting two aqueous streams from the UREX process to solid oxides. The UREX process is similar to the PUREX solvent-extractions process and is designed to separate $\mathrm{U}, \mathrm{Tc}$, and I from the transuranics and other fission products contained in spent fuel. It was determined that converting these waste streams to oxides is technically feasible by a combination of evaporation, denitration, and calcination.
\end{abstract}

\section{EXECUTIVE SUMMARY}

Accelerator Driven Transmutation of Waste (ATW) provides an alternative to the direct disposition of spent nuclear fuel by converting the transuranic elements and long-lived fission products contained in this waste to stable or short-lived fission products. Key to the success of ATW is the development of the UREX solvent-extraction process, which would separate U, Tc, and I from the transuranics and other fission products contained in spent fuel.

This report summarizes a literature survey on potential means for converting two aqueous effluents from the UREX solvent-extraction process to solid oxides. One stream is the uranium product. This stream will be essentially pure uranium nitrate hexahydrate (UNH) in dilute nitric

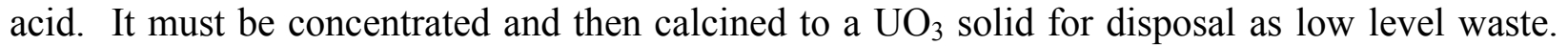
The second stream is the raffinate from the extraction section. This stream will contain 1-3 M $\mathrm{HNO}_{3}$ and essentially all the fission-product and transuranic isotopes. This stream must be converted to a solid oxide for feed to the PYRO-A process, which partitions the transuranics from the fission products. Literature was reviewed on methods of concentrating, denitrating, and calcining these streams. The emphasis was on well-developed, industrial-scale operations. Conclusions drawn from this literature survey follow.

Transforming the uranium product stream of a PUREX process to $\mathrm{UO}_{3}$ by a combination of evaporation, denitration, and calcination is commonly practiced in the nuclear commercial and defense industries. Converting solutions of $\mathrm{UNH}$ in dilute nitric acid to $\mathrm{UO}_{3}$ is being done commercially in Europe and Japan. From the 1950s until recently, Department of Energy defense sites have been doing this operation routinely. Therefore, needs for R\&D would be only at the pilot-plant scale. The major purpose of this work would be (1) to regain U.S. experience and (2) to achieve process optimization under current environment, safety, and health (ES\&H) constraints. 
Transforming the raffinate of the UREX process to oxides by a combination of evaporation, denitration, and calcination is technically feasible. However, no industrial process is ongoing that takes this stream to an oxide product. The UREX raffinate stream differs from the PUREX high-level liquid wastes (HLLW) currently being treated in that it will contain the full complement of transuranic isotopes (TRU) from commercial fuel. Significant concentrations of plutonium in the raffinate require all tanks and equipment to be criticality safe by geometry. Further, in Europe and Japan, the raffinate is only concentrated and denitrated to the point that solids do not precipitate. The concentrated solution is then either neutralized with sodium hydroxide for storage or fed to a glass melter for disposal. The PUREX raffinate was calcined for storage at the Idaho National Engineering and Environmental Laboratory, but criticality was not of concern with this HLLW due to the low TRU content. For these reasons, the R\&D needs for the UREX raffinate are far greater than those for the uranium product.

The required combination of concentration, denitration, and calcination must be optimized for UREX raffinate treatment. Concentrating the raffinate while recovering the nitric acid for recycle by a combination of evaporation and chemical denitration is likely to lead to reduced capital and operating costs. Fluidized-bed calcination appears to be the best method for forming the oxide, but designing a criticality-safe-by-geometry calciner could be a technical challenge. Storing and transporting the TRU-bearing oxide are challenging because of (1) criticality concerns due to its plutonium content and (2) the radiation field and heat output due to its ${ }^{137} \mathrm{Cs}$ and ${ }^{90} \mathrm{Sr}$ content. The chemical effects due to TRU content on calcining must also be studied.

\section{INTRODUCTION}

This report discusses potential means for converting two aqueous effluents from the UREX process to solid oxides. A literature review was conducted to look at methods of concentrating, denitrating, and calcining these streams. The emphasis was on well-developed, industrial-scale operations. The UREX process is a key step in the Accelerator-Driven Transmutation of Waste (ATW) treatment, an alternative to the direct disposition of spent nuclear fuel that involves converting the transuranic elements and long-lived fission products contained in the waste to stable or short-lived fission products [LAIDLER-1999]. Applying the ATW treatment to the nation's spent nuclear fuel would enhance the capability of the planned high-level waste repository and, perhaps, eliminate the need for an additional repository.

One stream from the UREX process is the uranium product. This stream will be essentially pure uranium nitrate hexahydrate (UNH) in dilute nitric acid. It must be concentrated and then calcined to a $\mathrm{UO}_{3}$ solid for disposal as low level waste. The second stream is the raffinate from the extraction section. This stream will contain 1-3 $\underline{M} \mathrm{HNO}_{3}$ and essentially all the fission products and transuranic isotopes. This stream must be converted to a solid oxide for feed to the PYRO-A process, which partitions the fission products and transuranics.

Concentration, denitration, and calcination of feeds close to those from the UREX process have been performed successfully in the nuclear industry throughout the world for decades. Many of the literature citations are $>40$ years old. It is not a question of can these 
streams be transformed to oxides, but what are the most economical and reliable means of doing so?

Section II summarizes information on the conversion of the uranium product to $\mathrm{UO}_{3}$ solid. Section III summarizes literature references on concentrating, denitrating, and calcining of high-level liquid waste (HLLW). Section IV concludes the report with technical needs. References are found in Section V.

\section{CONVERSION OF THE URANIUM PRODUCT TO UO 3}

Conversion of dilute nitrate solution to uranium oxide product has been reviewed [SHAW1961]. This operation requires high throughput, criticality control (especially for high enrichments), low uranium loss, and high purity of the uranium 1 . Control of dust is also very important due to potential contamination of the plant.

Denitration to $\mathrm{UO}_{3}$ is a two-step process. The first step is to concentrate the solution to a molten hydrated salt of uranium nitrate with a composition of essentially $\mathrm{UO}_{2}\left(\mathrm{NO}_{3}\right)_{2} \bullet 6 \mathrm{H}_{2} \mathrm{O}$. The second step is the thermal decomposition of this molten salt to granular uranium trioxide. The batch process [SHAW-1961] uses an evaporator followed by a boil-down tank to concentrate the feed to approximate the composition of $\mathrm{UO}_{2}\left(\mathrm{NO}_{3}\right)_{2} \bullet 6 \mathrm{H}_{2} \mathrm{O}(\mathrm{UNH})$. Leaving the evaporator, the concentrate is fed to a hold tank, where it is fed in batches to the denitration pot. This pot was made of Type 347 stainless steel to minimize contamination by corrosion products. The denitration step diagrammed in Shaw et al. (Fig. 8.1) processed 275 gal (1040 L) in 10 hours. The product is removed from the pot by vacuum "gulping." The $\mathrm{UO}_{3}$ product must be pulverized before further processing. Table 1 gives the approximate composition of various process streams.

Table 1. Major-Constituent Composition of Process Streams for Batch Generation of $\mathrm{UO}_{3}$

\begin{tabular}{lccccc}
\hline \multicolumn{1}{c}{ Stream } & {$[\mathrm{U}]$} & {$\left[\mathrm{HNO}_{3}\right]$} & $\begin{array}{c}{[\mathrm{Fe}]{ }^{\mathrm{b}}{ }^{\mathrm{p}}} \\
\mathrm{ppm}\end{array}$ & $\begin{array}{c}{[\mathrm{Ni}]{ }^{\mathrm{b}},} \\
\mathrm{ppm}\end{array}$ & {$[\mathrm{TBP}]$} \\
\hline Evaporator Feed & $90 \mathrm{~g} / \mathrm{L}$ & $0.03 \underline{\mathrm{M}}$ & 5 & 3 & $0.08 \mathrm{~g} / \mathrm{L}$ \\
Evaporator Product & $360 \mathrm{~g} / \mathrm{L}$ & $0.15 \underline{\mathrm{M}}$ & 10 & 3 & $0.02 \mathrm{~g} / \mathrm{L}$ \\
Boil-Down Product & $49.5 \%$ & $0.0 \%$ & 15 & 5 & $0.0 \%$ \\
$\mathrm{UO}_{3}$ Product & $82.5 \%$ & $-^{\mathrm{a}}$ & 25 & 5 & - \\
\hline
\end{tabular}

a The product was determined to contain $0.5 \%$ nitrate.

${ }^{\mathrm{b}}$ The $\mathrm{Fe}$ and $\mathrm{Ni}$ are from corrosion of the stainless steel equipment.

\footnotetext{
${ }^{1}$ For producing a uranium-oxide product for waste, purity concerns are far less important so long as the pertinent regulatory requirements on purity are met.
} 
Pot denitration is a batch process and has several disadvantages:

- High installation cost

- Low heating efficiency

- Manual operation

- Pot failure due to stress cracking.

Therefore, continuous processes were developed for this operation. Continuous processes cited by Shaw et al. are:

- $\quad$ Fluidized bed [JONKE-1957, KNECHT-1997]

- Moving beds [CATALYST-1953, MOORE-1955]

- Spray calciners [ALLEN-1949, ROSZKOWSKI-1953]

- Drum-drying calcination [SHAPIRO-1955]

- Agitated-trough calcination [SHAW-1961]

- Other processes [SHEPARDSON-1959, LOUDIN-1961]

Of the above, spray and agitated-trough calciners appear to have the greatest potential for high throughput and ease of operation. Shaw et al. discussed the agitated-trough calciner in detail. The calcined product from this unit was uniform, spherical pellets that would be easily transferred and would eliminate a serious fine-particulate problem caused by pulverization.

Chemical denitration by ammonia and/or hydrogen peroxide was also discussed. In the United States, these processes were used almost exclusively for highly enriched uranium [GOOGIN-1961, GRAINGER-1956, BARD-1954, THOMPSON-1961]. The ammonia process has been used in Great Britain [BARD-1954]. The peroxide process has been used in France [GOLDSCHMIDT-1956] and Belgium [BELGIUM-1956] for normal uranium production.

\section{CONVERSION OF THE UREX RAFFINATE TO SOLID OXIDES}

The UREX raffinate stream will contain essentially all components of the original fuel but the hardware, cladding, iodine, and uranium. The fuel will be chopped and leached, and $99 \%$ of the iodine will be scrubbed from the off-gas during dissolution in nitric acid. The uranium will be extracted by the UREX solvent; residual uranium will be $<0.1 \%$ of that in the fuel. About $1 \%$ of the solid content of the raffinate from PUREX plants comes from stainlesssteel corrosion products [MERZ-1986]; this would also be expected from a UREX plant. The UREX process is being developed so that no additives will add to the mass of the solidified stream. The nitric acid concentration in this stream will be between 1 and $3 \underline{\mathrm{M}}$.

\footnotetext{
${ }^{2}$ The fate of ${ }^{99} \mathrm{Tc}$ is controlled by the chemistry of the aqueous separation. Recent results verifying the proposed UREX flowsheet [LAIDLER-1999] showed that most of the ${ }^{99} \mathrm{Tc}$ would report to the raffinate. However, modifications to that flowsheet could allow extraction and subsequent stripping of technetium into a separate product stream. Another possibility is separation of technetium from the raffinate following UREX and before solidification.
} 
Converting the raffinate to an oxide solid c7alls for a combination of concentration, denitration, and calcination. The first two operations are standard for reprocessing plants, and industrial experience is plentiful [MERZ-1986, BRESCHET-1986, CÉCILLE-1986A, CÉCILLE-1986B, CÉCILLE-1986C, KLONK-1986, BRAY-1963]. The entire denitration process can be performed thermally; however, evaporation is limited by the formation of an azeotrope at $38.3 \mathrm{~mol} \%$ nitric acid. Because both water and nitric acid are being removed at the azeotrope, solid precipitation will occur as the solution is concentrated. Therefore, evaporation is only part of the answer. Foaming, scaling, and corrosion are common problems in a liquid waste evaporator. Further, concentration followed by calcination is typified by the formation of aerosols and an oxidizing environment, which promote undesired volatilization of some elements in the off-gas. Difficulties can also be encountered in (1) thermal decomposition due to the nitrate salts melting before decomposition, and forming syrupy concentrates and (2) decrepitation of solid particles. Both these concerns add to control problems and off-gas contamination. However, solidification of concentrated PUREX raffinate was performed successfully at the Idaho National Engineering and Environmental Laboratory (INEEL) for decades using fluidized-bed calcination [KNECHT-1997].

Other means of denitration (e.g., high temperature/pressure thermochemical [COX-1992] and supercritical-water oxidation [ROBINSON-1993]) have been studied, but they have maturity and large-scale-practicality concerns. Electrochemical denitration has also been advanced over the years. Its major advantages are: (1) does not require chemical addition, (2) in principle, should be easily controlled, and (3) all nitrate (nitric acid and nitrate salts) could be destroyed by this method. However, this technology has many practical problems that have kept it from becoming a functioning industrial-scale alternative [MERZ-1986]. Chemical denitration, mostly with simultaneous concentration by evaporation, will be discussed below, followed by INEEL experience with fluidized-bed calcining.

\section{A. $\quad$ Chemical Denitration}

Chemical denitration is widely used. Typical denitration agents are formic acid, formaldehyde, and sugar. ${ }^{-}$Formaldehyde and formic acid are by far the most studied and employed. Sugar denitrates in a controlled, but slow fashion. It allows the use of uncomplicated equipment, and sugar costs less than formic acid and formaldehyde. However, sugar denitration is likely to become the rate-controlling step of a waste treatment process. Its use during spray calcining of high-sodium waste destroyed the nitrate and produced a denser, free-flowing product. The French AVM process adds sugar in operating its rotary kiln. Denitration with sugar is slower but, on the positive side, requires no special controls. The overall reaction can be written:

\footnotetext{
${ }^{3}$ The following references provide details on the reaction of nitric acid and nitrate salts with formic acid: [BRADLEY-1972, BRESCHET-1986, CÉCILLE-1986A, CÉCILLE -1986C, COX-1992, GERMAIN-1974, HEALY-1956, HEALY-1958, HOLZE-1979, HOLZE-1980, KELM-1985, KUBOTA-1979, MERZ-1986, MORRIS-1957, OREBOUGH-1976, SAUM-1981].

${ }^{4}$ The following references provide details on the reaction of nitric acid and nitrate salts with formaldehyde: [CÉCILLE-1980, CÉCILLE-1986A, CÉCILLE-1986B, DIX-1985, EVANS-1956, FORSMAN-1963, HALASZOVICH-1985, HALASZOVICH-1986, HEALY-1954, HEALY-1956, HEALY-1958, KOCH-1972, MERZ-1986, MORRIS-1957].

${ }^{5}$ The following references provide details on the reaction of nitric acid and nitrate salts with sugar: [BRAY-1963, GOMPPER-1986, JOHNSON-1961, MACDOUGALL-1982]
} 


$$
\mathrm{C}_{12} \mathrm{H}_{22} \mathrm{O}_{11}+48 \mathrm{HNO}_{3} \rightarrow 48 \mathrm{NO}_{2}+12 \mathrm{CO}_{2}+35 \mathrm{H}_{2} \mathrm{O}
$$

Alternatives to formaldehyde, formic acid, and sugar have been studied, hut none has shown sufficient benefit for their development to be taken above laboratory studies.

An added benefit of chemical denitration is that volatilization of ruthenium 7 [ODOJ1980], and presumably other volatile species, will be significantly reduced in the subsequent calcining operation. Further, although the addition of formaldehyde or formic acid destroys nitrate, they do not depassivate stainless steel--thus lessening corrosion concerns [DUKE-1960].

\section{Chemistry of Denitration by $\mathrm{HCO}_{2} \underline{\mathrm{H} \text { and } \mathrm{HCHO}}$}

Denitration results quoted in the literature are often different and, in some cases, contradictory [MERZ-1986, CÉCILLE-1986A]. The multiple oxidation states of nitrogen and the differences in solution composition, the redox condition, and process conditions lead to five main reactions of nitric acid with formic acid and formaldehyde [HEALY-1954, HEALY-1956, HEALY-1958, HOLZE-1979, HOLZE-1980, HALASZOVICH-1986, KOCH-1972]. For formic acid, the reactions under a variety of conditions are shown in Table 2. Table 3 shows the formaldehyde reactions. The similarities between these reaction sets are tied to the fact that the first step in oxidation of formaldehyde is the formation of formic acid. Data presented in [HALASZOVICH-1986] show the striking similarity of reaction products for formic acid and formaldehyde destruction of nitric acid when the processing conditions are identical. These data are presented in Table 4.

\footnotetext{
${ }^{6}$ Gompper summarized alternatives that have been considered [GOMPPER-1986]. Along with sugar, alternatives discussed were (1) organic complexing agents (citric acid, EDTA, tartaric acid, and oxalic acid), (2) glycerin [RICHTER-1974], (3) ethanol, and (4) diethyl oxalate [GOMPPER-1985]. Very little is said about the first two reductants on the above list. Glycerin is only applicable at high nitric acid concentrations, and complexation agents are said to be effective in a radiation field. Denitration by diethyl oxalate is essentially denitration by ethanol; its reaction with nitric acid begins with an induction period, when ethanol is formed from the hydrolysis of the ester. The predominant reactions of ethanol and nitric acid can be written:
}

$$
\begin{aligned}
2 \mathrm{C}_{2} \mathrm{H}_{5} \mathrm{OH}+6 \mathrm{HNO}_{3} & \rightarrow 3 \mathrm{~N}_{2} \mathrm{O}+4 \mathrm{CO}_{2}+9 \mathrm{H}_{2} \mathrm{O} \\
\mathrm{C}_{2} \mathrm{H}_{5} \mathrm{OH}+4 \mathrm{HNO}_{3} & \rightarrow 4 \mathrm{NO}+2 \mathrm{CO}_{2}+5 \mathrm{H}_{2} \mathrm{O}
\end{aligned}
$$

Ethanol denitration has some advantages over formic acid and formaldehyde. These include:

- $\quad$ Less off-gas is produced per mole of nitric acid destroyed.

- Less ethanol is required per mole of nitric acid.

- $\quad$ Ethanol is a much cheaper reagent.

- At $75-80^{\circ} \mathrm{C}$, the reaction does not have an induction period.

- Excess alcohol can be recovered by distillation.

On the negative side:

- This reaction has been far less studied and has many unanswered chemistry and process concerns.

- Flammability of the off-gas stream is a safety concern.

${ }^{7}$ Decreasing the nitrate concentration in the feed to a glass melter from 10 to $\sim 0.3 \underline{\mathrm{M}}$ decreased the Ru volatilization by four orders of magnitude. This would very likely be true in calcination. 
Table 2. Reactions of Nitric Acid with Formic Acid under Various Conditions

\begin{tabular}{|c|c|}
\hline Process Conditions & Principal Reaction \\
\hline$\left[\mathrm{HNO}_{3}\right]>8 \underline{\mathrm{M}}$ & $2 \mathrm{HNO}_{3}+\mathrm{HCOOH} \rightarrow 2 \mathrm{NO}_{2}+\mathrm{CO}_{2}+2 \mathrm{H}_{2} \mathrm{O}$ \\
\hline \multirow{2}{*}{$0.5 \underline{\mathrm{M}}<\left[\mathrm{HNO}_{3}\right]<8 \underline{\mathrm{M}}$} & $\begin{array}{l}2 \mathrm{HNO}_{3}+2 \mathrm{HCOOH} \rightarrow \mathrm{NO}+\mathrm{NO}_{2}+2 \mathrm{CO}_{2}+3 \\
\mathrm{H}_{2} \mathrm{O}\end{array}$ \\
\hline & $2 \mathrm{HNO}_{3}+3 \mathrm{HCOOH} \rightarrow 2 \mathrm{NO}+3 \mathrm{CO}_{2}+4 \mathrm{H}_{2} \mathrm{O}$ \\
\hline Moderate Excess of $\mathrm{HCOOH}$ & $2 \mathrm{HNO}_{3}+4 \mathrm{HCOOH} \rightarrow \mathrm{N}_{2} \mathrm{O}+4 \mathrm{CO}_{2}+5 \mathrm{H}_{2} \mathrm{O}$ \\
\hline Large Excess of $\mathrm{HCOOH}$ & $2 \mathrm{HNO}_{3}+5 \mathrm{HCOOH} \rightarrow \mathrm{N}_{2}+5 \mathrm{CO}_{2}+6 \mathrm{H}_{2} \mathrm{O}$ \\
\hline
\end{tabular}

Table 3. Reactions of Nitric Acid with Formaldehyde under Various Conditions

\begin{tabular}{|c|c|}
\hline Process Conditions & Principal Reaction \\
\hline$\left[\mathrm{HNO}_{3}\right]>8 \underline{\mathrm{M}}$ & $4 \mathrm{HNO}_{3}+\mathrm{HCHO} \rightarrow 4 \mathrm{NO}_{2}+\mathrm{CO}_{2}+3 \mathrm{H}_{2} \mathrm{O}$ \\
\hline \multirow[t]{2}{*}{$0.5 \underline{\mathrm{M}}<\left[\mathrm{HNO}_{3}\right]<8 \underline{\mathrm{M}}$} & $\begin{array}{l}4 \mathrm{HNO}_{3}+2 \mathrm{HCHO} \rightarrow 2 \mathrm{NO}+2 \mathrm{NO}_{2}+2 \mathrm{CO}_{2}+ \\
4 \mathrm{H}_{2} \mathrm{O}\end{array}$ \\
\hline & $4 \mathrm{HNO}_{3}+3 \mathrm{HCHO} \rightarrow 4 \mathrm{NO}+3 \mathrm{CO}_{2}+5 \mathrm{H}_{2} \mathrm{O}$ \\
\hline Moderate Excess of $\mathrm{HCHO}$ & $4 \mathrm{HNO}_{3}+4 \mathrm{HCHO} \rightarrow 2 \mathrm{~N}_{2} \mathrm{O}+4 \mathrm{CO}_{2}+6 \mathrm{H}_{2} \mathrm{O}$ \\
\hline Large Excess of $\mathrm{HCHO}$ & $4 \mathrm{HNO}_{3}+5 \mathrm{HCHO} \rightarrow 2 \mathrm{~N}_{2}+5 \mathrm{CO}_{2}+7 \mathrm{H}_{2} \mathrm{O}$ \\
\hline
\end{tabular}

Table 4. Effects of Operating Conditions on the Composition of the NitrogenOxide-Containing Off-gas for the Reaction between a Solution of Nitric Acid and Sodium Nitrate with either Formic Acid or Formaldehyde ${ }^{a}$

\begin{tabular}{lcccccc}
\hline & \multicolumn{5}{c}{ Addition of Either HCOOH or HCHO, ${ }^{\mathrm{b}}$} \\
\cline { 2 - 7 } Operation & \multicolumn{2}{c}{$\mathrm{NO}^{\mathrm{c}}$} & \multicolumn{2}{c}{$\mathrm{NO}_{2}{ }^{\mathrm{c}}$} & \multicolumn{2}{c}{$\mathrm{N}_{2} \mathrm{O}^{\mathrm{c}}$} \\
& $\mathrm{HCOOH}$ & $\mathrm{HCHO}$ & $\mathrm{HCOOH}$ & $\mathrm{HCHO}$ & $\mathrm{HCOOH}$ & $\mathrm{HCHO}$ \\
\hline $\begin{array}{l}\text { Organic fed into } \\
\text { boiling nitrate }\end{array}$ & 68 & 71 & 4 & 5 & 28 & 24 \\
$\begin{array}{l}\text { Nitrate fed into } \\
\text { boiling organic }\end{array}$ & 22 & 28 & 3 & 2 & 75 & 70 \\
\hline
\end{tabular}

\footnotetext{
${ }^{a}$ Cécille and Kelm did not provide any information on the compositions of the feeds, volumes, equipment, etc. [CÉCILLE-1986A].

${ }^{b}$ It was not specified if these were volume, mole, or mass percentages.

${ }^{\mathrm{c}}$ Gas composition is the average of the compositions measured throughout the denitration experiments. Because it is a batch process, the concentrations of $\mathrm{HCOOH} / \mathrm{HCHO}$ and nitrate vary with time.
} 
The main emphasis on nitrate destruction research has actually been on nitric acid destruction. In general, chemical denitration proceeds until the only nitrate remaining is from alkali and alkaline-earth salts. These salts can only be denitrated with great difficulty; complete removal of nitrate from solutions with high sodium content is impossible. Destruction of nitrate salts by formic acid can follow two paths--formation of hydroxides (exemplified by the reaction of ferric nitrate) and formation of formate salts (exemplified by the destruction of aluminum nitrate) [OREBOUGH-1976]. These reactions are:

$$
\begin{gathered}
2 \mathrm{Fe}\left(\mathrm{NO}_{3}\right)_{3}+9 \mathrm{HCOOH} \rightarrow 6 \mathrm{NO}+9 \mathrm{CO}_{2}+6 \mathrm{H}_{2} \mathrm{O}+2 \mathrm{Fe}(\mathrm{OH})_{3} \\
2 \mathrm{Al}\left(\mathrm{NO}_{3}\right)_{3}+18 \mathrm{HCOOH} \rightarrow 3 \mathrm{~N}_{2} \mathrm{O}+12 \mathrm{CO}_{2}+15 \mathrm{H}_{2} \mathrm{O}+2 \mathrm{Al}(\mathrm{HCOO})_{3}
\end{gathered}
$$

Addition of phosphoric acid will allow almost complete destruction of nitrate [DIX-1985]. However, the consequences of phosphate in the product must be analyzed.

The actual mechanism for the denitration is far more complex than suggested by the above equations. Denitration reactions are generally characterized by an induction period, which is detrimental to process control and is a significant safety concern. A slow startup of the reaction could lead to a buildup of reactants, which, when the reaction takes off, could overpressurize the reaction vessel. Four parameters appear to affect the duration of the induction period for nitric acid destruction by formaldehyde or formic acid:

- Temperature $^{\mathrm{B}}$

- Concentrations of the reductant and nitric acid

- Concentration of nitrous acid

- Surface state of the reactor walls

The need to build up a steady-state concentration of $\mathrm{HNO}_{2}$ appears to be the overriding reason for the induction period. It is believed that the induction period is the time necessary for the concentration of nitrous acid to build up to a threshold concentration between 0.01 and $0.1 \underline{\mathrm{M}}$ [LONGSTAFF-1954, KUBOTA-1979, GERMAIN-1974]. Adding sodium nitrite to the mixture can be used to eliminate the induction period [KUBOTA-1979].

Several researchers have studied the rate of destruction of nitric acid by formaldehyde [MORRIS-1957] and formic acid [MORRIS, HEALY-1956, HOLZE-1980, SAUM-1981] under a variety of conditions. The rate laws vary but, in general, show higher-than-first-order dependencies for both the organic-reductant and nitric-acid concentrations. The presence of nitrate salts increases the denitration rate; this is easily explained by a higher nitrate concentration in the reaction vessel. Increasing the overpressure also appears to increase the reaction rate; this can be explained by $\mathrm{NO}_{2}$ being an important intermediate in the reaction. Denitration is performed at a slight overpressure $\left(+100-\mathrm{mm} \mathrm{H}_{2} \mathrm{O}\right)$ at the CEA-Fontenay-auxRoses [CÉCILLE-1986B]. Substituting argon for air in the reactor has no significant effect on the rate. Bubbling air through the mixture lowers the rate, apparently due to its removing the gaseous reactants from solution [CÉCILLE-1980]. An increase in the rate due to the presence of

\footnotetext{
${ }^{8}$ At temperatures $100^{\circ} \mathrm{C}$, the induction period is minimal.
} 
noble metals ( $\mathrm{Rh}$ and $\mathrm{Pd}$ ) is marginal; however, they may affect the consumption of the reductants by secondary reactions and may affect the rate oscillations sometimes seen in nitrate destruction [HOLZE-1980, KRAUSE-1972, SAUM-1981].

A possible mechanism for the overconsumption of the organic reductant is shown for the catalyzed destruction of formic acid by palladium in the following equations:

$$
\begin{gathered}
\mathrm{Pd}^{2+}+\mathrm{HCOOH} \rightarrow 2 \mathrm{H}^{+}+\mathrm{CO}_{2}+\mathrm{Pd}_{\text {(black) }} \\
\mathrm{HCOOH} \stackrel{\mathbf{P d}_{\text {(black) }}}{\rightarrow} \mathrm{H}_{2}+\mathrm{CO}_{2}
\end{gathered}
$$

These reactions have serious consequences. Production of hydrogen gas is a significant safety concern. Studies of off-gas compositions have found $\mathrm{H}_{2}$ gas to be $10 \mathrm{vol} \%$ under some conditions. Another important effect of the presence of noble metals, especially when palladium and iron are present in the solution, is oscillation in the reaction rate and, therefore, the off-gas generation [HOLZE-1980]. This effect is most often seen when nitric acid is slowly fed into boiling formic acid. The effect can be explained by the nitrous acid concentration increasing and decreasing due to the buildup and dissolution of palladium black, with the $\mathrm{Fe}(\mathrm{III}) /(\mathrm{II})$ couple acting catalytically. Noble metals catalysis may also convert NO gas to ammonia under some conditions.

\section{Industrial Denitration of Radioactive Waste}

Klonk and Stehle looked into ecconomic incentives for denitration of two streams: (1) the PUREX first-cycle raffinate (HAW) ${ }^{9}$ and (2) a combined concentrate from secondary processrelated streams (MAWC) [KLONK-1986]. The main objection to chemical denitration in a fuelprocessing plant is the safety and material-handling concerns associated with formaldehyde and formic acid. (These concerns will be discussed in a following section.) In addition, to be used in a plant, the denitration process must be easily controlled and not result in foaming or solids formation. Even with these concerns, there are strong justifications for considering denitration of these waste streams:

- The corrosion of downstream equipment is decreased.

- Radioactivity in the off-gas streams is reduced.

- The nitrogen oxides in the off-gas can be reconverted to nitric acid and the nitric acid recycled to the dissolver.

- If neutralization of the streams is required for storage or disposal, the amount of sodium nitrate generated is reduced. Also, the disposed or stored waste will have a smaller volume.

For these reasons, chemical denitration was selected for the 2-ton/day Wackersdorf Reprocessing Plant. The plant designers chose formaldehyde for denitration of the HAW and formic acid for MAWC denitration. At the time of this decision, the formaldehyde denitration was already in

\footnotetext{
${ }^{9}$ Also designated as high-level liquid waste (HLLW).
} 
operation at AVM at Marcoule, and the formic-acid denitration had not yet been demonstrated using radioactive feeds.

Before denitration, the HAW was to be steam-stripped and concentrated ten times in a pot evaporator, with a continuous feed and batch take off. The nitric acid was steam distilled to give $1.5 \underline{\mathrm{M}} \mathrm{HNO}_{3}$. The denitrator was a pot-type evaporator heated by pressurized water at $150^{\circ} \mathrm{C}$. One batch of $3.8 \mathrm{~m}^{3}$ took 40 hours for denitration and 56 hours for the entire process. The reaction products were recombined to form nitric acid for recycle. In this 2-ton/day reprocessing plant, this recycle was estimated to be 60 tons of nitric acid per year, $13 \%$ of the nitric acid balance.

The nitric acid concentration in low- or medium-activity waste streams for typical plants was expected to be $\sim 0.16 \underline{\mathrm{M}}$. The waste solutions were to be concentrated by a factor of 20 . Denitration would occur in a pot-type evaporator heated by pressurized water at $135^{\circ} \mathrm{C}$. The vessel is initially filled with the required amount of formic acid, which is brought to boiling. A volume of $950 \mathrm{~L}$ of concentrate is fed to the pot during a five-hour period. An additional five hours is required to complete the reaction, destroy excess formic acid with hydrogen peroxide, and concentrate the remaining salt solution. Because the amount of nitric acid is small for this stream, nitrogen reaction products would be acceptable for release rather than recycle.

Cécille and Lecomte looked at denitrating actual high-level liquid waste (HLLW) in a pilot-scale facility [CÉCILLE-1986C]. Before denitration with formic acid, 50 L of PUREX raffinate $\left(3.3 \underline{\mathrm{M} \mathrm{HNO}_{3}}\right.$ ) was concentrated by a factor of five. Denitration by a 1-to-1 mole ratio of formic acid to nitric acid brought the nitric acid down from 12.8 to $4.7 \underline{\mathrm{M}}$. Concentrated formic acid was added to the $80^{\circ} \mathrm{C} \mathrm{HLLW}$ at a rate of $500 \mathrm{~mL} / \mathrm{h}$. The reactants were then kept at $80^{\circ} \mathrm{C}$ for 4 hours under slight overpressure. The final concentration of nitric acid was $4.7 \mathrm{M}$. Following a second concentration step, $4 \mathrm{~L}$ of HLLW was denitrated to $3 \underline{\mathrm{M}} \mathrm{HNO}_{3}$. No precipitates were formed if the nitric acid concentration was kept above $3 \underline{\mathrm{M}}$. A third denitration brought the concentration of nitric acid down to $1.08 \underline{\mathrm{M}}$. After cooling, $\sim 200 \mathrm{~mL}$ of black precipitate was filtered and found to contain $30 \%$ of the plutonium. The volume of the filtrate was not given.

Thirty years' experience in the use of formaldehyde to denitrate HLLW has shown it to be reliable and safe [BRESCHET-1986]. Evaporation and denitration are run in a kettle-type evaporator with external heating. A condenser with partial reflux recombines $\mathrm{NO}_{\mathrm{x}}$ to form nitric acid. Recombination is completed in a separate unit that adds oxygen to prepare nitric acid for recycle to the plant. The unit is started up by bringing the HLLW to a boil. A small amount of sodium nitrite is added, and then starting the HCHO feed begins the denitrating process. The process is semicontinuous; the HLLW is added at a continuous rate while formaldehyde is added at a rate dependent on the gas generation. The liquid level in the evaporator is kept constant and can be controlled by the flow rate of formaldehyde, heating power to the evaporator, and/or the feed flow rate. Acidity of the concentrate is checked at least twice per day by sampling. At shutdown, the evaporator is put in total reflux to destroy any remaining $\mathrm{HCHO}$ and by-products. Heat to the evaporator is then stopped. When the temperature reaches $60^{\circ} \mathrm{C}$, the HLLW concentrate is transferred to storage by a steam jet. The HLLW product is concentrated by about a factor of 20 during this operation. 
The French Company SGN has designed several of these concentration/denitration units for use at Marcoule and La Hague in France and for Tokai-Muri in Japan. The concentrated product is 1-3 $\underline{\mathrm{M}} \mathrm{HNO}_{3}$ to avoid precipitation of solids. The decontamination factor of the overheads is usually $10^{6}-10^{8}$. Concentration factors are not limited by the process, but by the salt content (solubility limits) or specific heat requirements of the plant. Safety concerns associated with the potential for an induction period are minimized by starting with a hot feed $\left(95^{\circ} \mathrm{C}\right.$ ), the acidity of the feed (free acid is maintained at $\sim 2 \mathrm{M}$ ), and addition of sodium nitrite $(100-200 \mathrm{mg} / \mathrm{L})$.

\section{3. $\quad$ Safety Concerns}

According to Merz, formic acid should always be added to a boiling waste solution under a slow purge of inert gas [MERZ-1986]. Doing so avoids safety problems due to (1) loss of control of the reaction, (2) formation of explosive formic-acid/air mixtures, and (3) formation of formate-salt precipitates.

Schulenberg performed a safety analysis on the use of formic acid to denitrate high-level PUREX process waste of a planned German reprocessing plant [SCHULENBERG-1986]. In the planned process, PUREX raffinate would be fed batchwise to boiling formic acid. The formic acid would be three times that required to reduce the nitric acid. The vessel analyzed was sized to treat $100 \mathrm{~L}$ of raffinate per batch with a design pressure of $3 \mathrm{~atm}$. It was heated on the outside by 3 -atm steam $\left(133^{\circ} \mathrm{C}\right)$. With no water vapor present, a gas mixture of air with 17 to $61 \mathrm{vol} \%$ formic acid can be explosive. A minimum ignition temperature of $520^{\circ} \mathrm{C}$ is required [KELM1987]. A critical gas composition (air/formic-acid/water-vapor) will always occur in the denitration vessel when the formic acid is pretreated if the vessel initially contained air. Further, it is likely to be present during the first 10-20 minutes of liquid-waste addition. However, when the formic acid concentration in the liquid falls below $20 \underline{\mathrm{M}}$, the gas composition becomes subcritical. With no evident ignition source the risk of explosion is considered low. The risk can be lowered further by (1) using nitrogen as a sweep gas and (2) designing the vessel and off-gas system to withstand pressures of $10 \mathrm{~atm}$, which is considerably higher than the calculated (5.5 $\mathrm{atm})$ and observed $(3.7 \mathrm{~atm}$.) maximum explosion pressure. At boiling temperatures, the reaction rate (and, therefore, the gas-production rate) increases linearly with the waste-addition rate. In the German system, increasing the feed rate by 10 would not generate a critical mass flux. However, if the feed is added before boiling temperature is reached, nitric acid could build up because of the induction period. Since the induction period is inversely dependent on the temperature of the solution, Schulenberg recommends that both the solution temperature and the gas generation rate be monitored as controls for the feed rate [SCHULENBERG-1986]. Moreover, the feed rate should be low until gas production is seen.

Plant experience with formaldehyde denitration has showed it to be safe and reliable [BRESCHET-1986, KLONK-1986].

Whenever heating of PUREX aqueous streams is anticipated, "Red-Oil" is a topic of discussion. Violent degradation of "Red-Oil" was measured by Nichols in 1960 at temperatures above $130^{\circ} \mathrm{C}$ [NICHOLS-1960]. The exact composition of "Red-Oil" is not known, but it is composed of complexes of tributyl phosphate (TBP) and its degradation products with nitric acid. Also, heavy metals are considered to play an important role in Red Oil's degradation. It is 
believed that adding the waste to boiling formic acid would be advantageous to preventing violent reaction. If $\mathrm{TBP} /$ nitric-acid complexes were in the solution, they would be added sparingly over time and, therefore, would not build up.

In summary, formic-acid and formaldehyde denitration of PUREX wastes is controllable. The oscillatory reaction is understood and means to avoid it are set. The temperature of the waste and the means of addition of the $\mathrm{HCO}_{2} \mathrm{H}$ or $\mathrm{HCHO}$ are critical to the control and, therefore, safety of the operation. Nuclear criticality has not been of concern for concentration of PUREX first-cycle raffinates. However, the UREX raffinate will contain significant quantities of plutonium. Therefore, as is standard for enriched-uranium- and plutonium-product streams, all equipment for the UREX raffinate must be criticality safe by geometry.

\section{B. $\quad$ Fluidized-Bed Calcination of the UREX Raffinate}

Use of a fluidized-bed calciner alleviates many of the concerns discussed above for calcining the UREX raffinate. The following summarizes the benefits of, and the Department of Energy experience in, using fluidized-bed calcining of nitric acid HLLW [KNECHT-1997].

The concept of calcining radioactive waste by atomizing the liquid in a heated bed of inert particles originated at Argonne National Laboratory (ANL) in the middle 1950s [JONKE1957, LOEDING-1961]. Pilot-plant demonstrations at ANL using simplated Idaho and Hanford

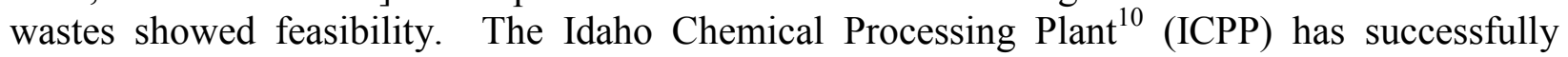
calcined high-level liquid waste from their PUREX operations for over three decades. Fluidizedbed calcination was chosen over pot, spray, and rotary-kiln calcination for treating Idaho HLW because it (1) is continuous, (2) is readily adaptable to remote operation, (3) has no moving parts to wear out, (4) had adequate throughput capacity to meet needs, and (5) was adequately developed for demonstration. Other benefits to fluidized-bed calcining found during Idaho demonstration were: (1) independence from complicated moving parts, (2) excellent control of bed temperature with uniform high heat-transfer rates, (3) adaptability to remote operation, and (4) excellent control of particle size and properties [COOPER-1965].

The WCF (Waste Calcining Facility) operated between December 1963 and October 1964 at ICPP. In that period, it calcined $1800 \mathrm{~m}^{3}$ of radioactive liquid waste, converting it to $210 \mathrm{~m}^{3}$ of solid calcine. The net output exceeded the design output by $15 \%$, and the process operated at $99 \%$ efficiency. Subsequently, the WCF was modified to run at higher throughput by installing an in-bed combustor that used oxygen-atomized kerosene. The use of in-bed combustion increased the operation temperature from 400 to $500^{\circ} \mathrm{C}$, increased the heat-transfer rates, decreased the volatilization of ruthenium by 100-200, and lowered the metal-wall temperatures. The WCF was operated until March 1981, calcining $15,000 \mathrm{~m}^{3}$ of liquid radioactive waste.

The NWCF (New Waste Calcining Facility), which was built to replace the WCF, began hot operation at ICPP in September 1982. Two major reasons for building a new waste calcining facility were (1) the time required for maintenance of the WCF without remote facilities and (2) the need to increase throughput. Between September 1982 and March 1984, the NWCF

\footnotetext{
${ }^{10}$ Presently named INTEC, Idaho Nuclear Technology and Engineering Center.
} 
processed $6000 \mathrm{~m}^{3}$ of waste; after that time, it ran out of available waste to process. After being fitted with a distributive control system, NWCF began treating a variety of waste feeds. As of May 1997, the NWCF had treated $12,100 \mathrm{~m}^{3}$ of liquid waste to produce $1670 \mathrm{~m}^{3}$ of calcine.

Again, because of the significant concentration of plutonium isotopes in the UREX raffinate, the calciner and its ancillary tanks and equipment must be criticality safe by geometry.

\section{CONCLUSIONS AND TECHNICAL NEEDS}

Transforming the uranium-product stream of the UREX process to $\mathrm{UO}_{3}$ by a combination of evaporation, denitration, and calcination is technically feasible. Converting the UNH in dilute nitric acid to $\mathrm{UO}_{3}$ is being done commercially in Europe and Japan and was performed in the United States for decades. Needs for R\&D would be only at the pilot-plant scale. The major functions of this activity would be to (1) regain U.S. experience and (2) define the optimal process under current ES\&H constraints.

Transforming the raffinate of the UREX process to oxides by a combination of evaporation, denitration, and calcination is also technically feasible. However, no industrial process is ongoing that takes this process to an oxide product. The UREX stream differs from the PUREX raffinates currently being concentrated and denitrated in that it will contain the full complement of transuranic isotopes from commercial fuel. Significant concentrations of plutonium in the raffinate require all tanks and equipment to be criticality safe by geometry. Further, in Europe and Japan, the raffinate is only concentrated and denitrated to the point that solids do not precipitate. The concentrated solution is then either neutralized with sodium hydroxide for storage or fed to a glass melter for disposal. The PUREX raffinate was calcined for storage at INEEL, but criticality was not of concern with their HLLW. For these reasons, the R\&D needs for the UREX raffinate are far greater than those for the uranium product.

The required combination of concentration, denitration, and calcination must be optimized for this stream. Concentrating the raffinate while recovering the nitric acid for recycle by a combination of evaporation and chemical denitration is likely to lead to reduced capital and operating costs. Fluidized-bed calcination appears to be the best method for forming the oxide, but designing a criticality-safe-by-geometry calciner could be a technical challenge. Storing and transporting the oxide are challenging because of (1) criticality concerns due to its plutonium content and (2) the radiation field and heat output due to its ${ }^{137} \mathrm{Cs}$ and ${ }^{90} \mathrm{Sr}$ content. The chemical effects due to TRU content on calcining must also be studied.

\section{ACKNOWLEDGMENTS}

This work is supported by the U. S. Department of Energy, Office of Nuclear Energy, Science and Technology, under Contract W-31-109-ENG-58. 


\section{REFERENCES}

[ALLEN-1949]

[BARD-1954]

[BELGIUM-1956]

[BRADLEY-1972]

[BRAY-1963]

[BRESCHET-1986]

[CATALYST-1953]

[CÉCILLE-1980]

[CÉCILLE-1986A]
A. L. Allen et al., Spray Decomposition of Uranyl Nitrate Solutions to Uranium Trioxide, USAEC Report K-444, Carbide and Carbon Chemicals Co., K-25 Plant (July 15, 1949).

R. J. Bard, Specific Surface and Bulk Density of $\mathrm{U}_{3} \mathrm{O}_{8}$ and $\mathrm{UO}_{2}$ as Factors in $U F_{4}$ Production on the 250-gram Uranium Scale, USAEC Report LA-1854, Los Alamos Scientific Laboratory (December 1954).

Anonymous, "Uranium Metallurgy in Belgium," Proc. of on the Peaceful Uses of Atomic Energy, Geneva, 8, 156-151 (1956).

R. F. Bradley and C. B. Goodlett, Denitration of Nitric Acid Solutions by Formic Acid, DP 1299, June 1972.

L. A. Bray and E. C. Martin, Denitration of Purex Wastes with Sugar, HW-76973, Rev., Hanford Atomic Products Operation (1963).

C Breschet, D. Pageron, F. Drain, and V. Decobert, "Industrial Application of Denitration of HLLW by Means of HCHO," L. Cécille and S. Halaszovich [Eds.], Denitration of Radioactive Liquid Waste, Radioactive Waste Management Series of the Commission of the European Communities Graham and Trotman, Norwell, MA, p. 162 (1986).

Catalyst Construction Co., New Moving-Bed Process for the Continuous Denitration of Uranyl Nitrate Hydrate, U.S. Atomic Energy Commission Report NYO-1181 (August 28, 1953).

L. Cécille and G. Tanet, "Etude de l'Influence de Quelues Paramétres sur la Réaction de Dénitration d'Une Solution HLLW Simulée--Schema de Séparation des Actinide HDEHP," Note technique $\mathrm{n}^{\circ}$ 1.07.03.80.98 - JRC Ispra (November 1980).

L. Cécille and M. Kelm, "Chemical Reactions Involved in the Denitration Process with $\mathrm{HCOOH}$ and HCHO," L. Cécille and S. Halaszovich [Eds.], Denitration of Radioactive Liquid Waste, Radioactive Waste Management Series of the Commission of the European Communities, Graham and Trotman, Norwell, MA p. 17 (1986).

\footnotetext{
${ }^{11}$ Not all references were available. They were taken from sources that were read and are given for completeness.
} 
[CÉCILLE-1986B]

[CÉCILLE-1986C]

[COOPER-1965]

[COX-1992]

[DIX-1985]

[DUKE-1960]

[EVANS-1956]

[FORSMAN-1963]

[GERMAIN-1974]

[GOLDSCHMIDT-1956]

[GOMPPER-1985]
L. Cécille and G. Lecomte, "Denitration of HLLW for Actinide Partitioning," L. Cécille and S. Halaszovich [Eds.], Denitration of Radioactive Liquid Waste, Radioactive Waste Management Series of the Commission of the European Communities, Graham and Trotman, Norwell, MA, p. 132 (1986).

L. Cécille and M. Lecomte, "Denitration of HLLW for Actinide Partitioning," L. Cécille and S. Halaszovich [Eds.], Denitration of Radioactive Liquid Waste, Radioactive Waste Management Series of the Commission of the European Communities, Graham and Trotman, Norwell, MA, p. 126 (1986).

E. D. Cooper, D. E. Black, and C. B. Amberson, "Pilot and PlantScale Fluidized Bed Calciners," Chem. Eng. Prog. 61, p. 89 (1965).

J. L. Cox, M. A. Lilga, and R. T. Hallen, Thermochemical Nitrate Reduction, PNL-8226, Pacific Northwest Laboratory (September 1992).

S. Dix, FIPS II-Denitrierungsanlage - Aufbau und Betriebserfahrungen, Report JUL-Spez-324, (1985).

E. M. Duke, Depassivation of 304L Stainless Steel in SULFEX Decladding Solutions, HW-65925, Hanford Atomic Products Operation (1960).

T. F. Evans, The Pilot Plant Denitration of PUREX Wastes with Formaldehyde, HAW-58587, Hanford Atomic Products Operation (1956).

R. C. Forsman and G. C. Oberg, Formaldehyde Treatment of Purex Radioactive Wastes, HW-79622, Hanford Atomic Products Operation (1963).

M. Germain, A. Bathellier, and P Bérard, "Use of Formic Acid for the Stripping of Plutonium," Proc. of Int. Solvent Extraction Conf. Lyon, p. 2075 (1974).

B. Goldschmidt and P. Vertes, The Preparation of Pure Uranium Metal, Proceedings of the International Conference on the Peaceful Uses of Atomic Energy, Geneva, 8, p. 152-155 (1956).

K. Gompper, "Mittelaktive Abfallösungen," Abtennung von Transuranelementen und SpaltproduktenAtomwirtshaftAtomtechnik 30, p. 90 (1985). 
[GOMPPER-1986]

[GOOGIN-1961]

[GRAINGER-1956]

[HALASZOVICH-1985]

[HALASZOVICH-1986]

[HEALY-1954]

[HEALY-1956]

[HEALY-1958]

[HOLZE-1979]

[HOLZE-1980]

[JOHNSON-1961]
K. Gompper, "Alternative Organic Reductants for Denitration," L. Cécille and S. Halaszovich [Eds.], Denitration of Radioactive Liquid Waste, Radioactive Waste Management Series of the Commission of the European Communities, Graham and Trotman, Norwell, MA, p. 32 (1986).

J. Googin, Union Carbide Nuclear Co., Y-12 Plant, personal communication. From [SHAW].

L. Grainger, "Production of Uranium Metal," Proc. of Int. Conf. on the Peaceful Uses of Atomic Energy, Geneva, 8, p. 152-155 (1956).

S. Halaszovich, S. Dix, R. Harms, and W. Schälich, "Auswahlkriterien für Denitrierungsverfahren in BrennelementWiedersaufarbeitungsanlagen," Atomkernenergie/Kerntecnik 47, p. 94 (1985).

S. Halaszovich, S. Dix, and R. Harms, "Denitration of Reprocessing Concentrate by Means of HCHO," L. Cécille and S. Halaszovich [Eds.], Denitration of Radioactive Liquid Waste, Radioactive Waste Management Series of the Commission of the European Communities, Graham and Trotman, Norwell, MA, p. 64 (1986).

T. V. Healy and B. L. Davis, The Destruction of Nitric Acid by Formaldehyde, Part I, AERE C/R 1339 (April 1954).

T. V. Healy and B. L. Davis, "The Destruction of Nitric Acid by Formaldehyde, Part II, III, and IV" AERE C/R 1739 (February 1956).

T. V. Healy, "The Reaction of Nitric Acid with Formaldehyde and with Formic Acid and Its Application to the Removal of Nitric Acid from Mixtures," J. Appl. Chem. 8, p. 553 (1958).

K. Holze, H. D. Finke, M. Kelm, and W. D. Deckwer, "Reaction Model for Denitration with Formic Acid of Waste Effluents from Nuclear Fuel Reprocessing Plants," Ger. Chem. Eng., 2, p. 361 (1979).

K. Holze, Dissertation, University of Hannover, (December 1980).

B. M. Johnson, Jr., Radiant Heat Spray Calcination, TID 7613, Bk. 1, p. 27 (1961). 
[JONKE-1957]

[KELM-1985]

[KELM-1987]

[KLONK-1986]

[KNECHT-1997]

[KOCH-1972]

[KRAUSE-1973]

[KUBOTA-1979]

[LAIDLER-1999]

[LOEDING-1961]
A. A. Jonke, E. J. Petkus, J. W. Loeding, and S. Lawroski, "The Use of Fluidized Beds for Continuous Drying and Calcination of Dissolved Nitrate Salts,” Nucl. Sci. Eng. 2, p. 303 (1957).

M. Kelm, B. Oser, S. Drobnik, and W. Bähr, Die chemische Denitrierung von salpetersauren schwach- und mittelaktiven losungen mit Ameisensäure, KfK 3948, Kernforchungszentrum Karlsruhe (1985).

M. Kelm, B. Oser, S. Drobnik, and W. D. Deckwer, "Denitration of Aqueous Waste Solutions from Nuclear Fuel Reprocessing," Nucl. Tech. 51, p. 27 (1987).

H. Klonk and M. Stehle, "Economical Aspects of Denitration in the Management of Reprocessing Concentrate," L. Cécille and S. Halaszovich [Eds.], Denitration of Radioactive Liquid Waste, Radioactive Waste Management Series of the Commission of the European Communities, Graham and Trotman, Norwell, MA, p. 47 (1986).

Deiter A. Knecht, M. Dan Staiger, Jerry D. Christain, C. Lee Bendixsen, G. W. (Bill) Hogg, and Julius R. Berreth, "Historical Fuel Reprocessing and HLW Management in Idaho," Radwaste Mag., 35 (May 1997).

G. Koch, Z. Kolarik, H. Haug, W. Hild, and S. Drobnik, Proceedings, Management of Radioactive Waste from Fuel Reprocessing, OECD, Paris, p. 1081 (1972).

H. Krause et al., Annual Report for 1972, KfK-2000 Kernforchungszentrum Karlsruhe (1973).

M. Kubota, I. Yamaguchi, and H. Nakamura, "Effects of Nitrite on Denitration of Nuclear Fuel Reprocessing Waste with Organic Reductants,” J. Nucl. Sci. Technol. 16, p. 6 (1979).

J. J. Laidler et al., Preparation of a Technology Development Roadmap for the Accelerator Transmutation of Waste (ATW) System: Report of the ATW Separations Technologies and Waste Forms Technical Working Group, ANL-99/15, Argonne National Laboratory, (August 1999).

J. W. Loeding, E. L. Carls, L. G. Anastasio, and A. A. Jonke, The Fluidized-Bed Calcination of Radioactive Waste, ANL-6322, Argonne National Laboratory (May 1961). 
[LONGSTAFF-1954]

[LOUDIN-1961]

[MACDOUGALL-1982]

[MERZ-1986]

[MOORE-1955]

[MORRIS-1957]

[NICHOLS-1960]

[ODOJ-1980]

[OREBOUGH-1976]

[RICHTER-1974]

[ROBINSON-1993]
J. V. L. Longstaff, and K. Singer, "The Kinetics of Oxidation by Nitric Acid and Nitrous Acid--Parts, I and II," J. Chem. Soc. p. 2604-2617 (1954).

D. J. Loudin and H. J. Cavendish, National Lead Co., Y-12 Plant, personal communication. From [SHAW].

C. S. MacDougall, C. K.Bayne, and R. B. Roberson, "Studies on the Reaction of Nitric Acid with Sugar," Nucl. Technol. 58, p. 47-52 (1982).

E. R. Merz, "Overview on the Application of Denitration in the Nuclear Field," L. Cécille and S. Halaszovich [Eds.], Denitration of Radioactive Liquid Waste, Radioactive Waste Management Series of the Commission of the European Communities, Graham and Trotman, Norwell, MA, p. 1 (1986).

J. E. Moore, M. A. Turner, and G. R. Quinn, Unit Operations Status Report for January 1955, USAEC Report CF-55-1-194, pp. 16-27 Oak Ridge National Laboratory (January 28, 1955).

J. B. Morris, "A Réaction de l'Acid Nitrique sur le Formaldehyde," Energie Nucléaire 1, 216 (1957).

G. S. Nichols, Decomposition of Tributyl Phosphate Complexes, DP-526 (1960).

R. Odoj, E. Merz, and S. Wolters, "Effects of Denitration on Ruthenium Volatilization," Scientific Basis for Nuclear Waste Management, Vol. 2, Plenum Publishing Corp., New York, p. 911 (1980).

E. G. Orebough, Denitration of Savannah River Plant Waste Streams, DP-1417 (1976).

H. Richter and H. Soratin, Zerstörung des Salpetersäureuberschusses in Radioaktiven Abfallösungen und Verfestigung des Rückstandes als Alkydharz, SGAE -2252 (1974).

J. M. Robinson, B. R. Foy, P. C. Dell'Orco, G. Anderson, F. Archleta, J. Atencio, D. Breshears, R. Brewer, H. Eaton, R. McFarland, R. McInroy, T. Reynolds, M. Sedillo, E. Wilmanns, and S. J. Buelow, Destruction of Nitrates, Organics, and Ferrocyanides by Hydrothermal Processing, LA-UR 93-456, Los Alamos Scientific Laboratory (1993) (Also, Proceedings of Waste Management Symposium 93, February 28 - March 4, 1993, Tucson, Arizona). 
[ROSZKOWSKI-1953]

[SAUM-1981]

[SCHULENBERG-1986]

[SHAPIRO-1955]

[SHAW-1961]

[SHEPARDSON-1959]

[THOMPSON-1961]
E. S. Roszkowski, Summary Report of the Long Range Program for the Period May 1, 1953 to July 31, 1953, USAEC Report NYO-2043, New Brunswick Laboratory, p. 112-115 (October 1953).

C. J. Saum, L. R. Ford, and R Blatts, "Denitration of Simulated Fast Reactor Highly Active Liquor Waste," DSO 7387 (S), Proc.of Int. Seminar on Chemistry and Process Engineering for High Level Liquid Waste Solidification-KFA, Jülich (June 1-5, 1981).

T. Schulenberg, "Safety Aspects about Denitration," L. Cécille and S. Halaszovich [Eds.], Denitration of Radioactive Liquid Waste, Radioactive Waste Management Series of the Commission of the European Communities, Graham and Trotman, Norwell, MA, p. 51 (1986).

T. Shapiro and R. J. Clouse, Production of $\mathrm{UO}_{3}$ by DryingCalcining, USAEC Report K-1239, Carbide and Carbon Chemicals Co., K-25 Plant (August 26, 1955).

W. E. Shaw, W. C. Manser, R. G. Geier, and S. H. Smiley, "Natural, Slightly Enriched, or Depleted Uranium Chemistry," in Reactor Handbook, 2nd ed., Vol. II, Fuel Reprocessing, M. Stroller and R. B. Richards [Eds.], Interscience Publishers, New York, p. 345 (1961).

J. U. Shepardson and J. A. Nelson [Eds.], Process Development Quarterly Report, Part II. Pilot Plant Work, USAEC Report, MCW-1420, Mallinckrodt Chemical Works (May 1, 1959). (Classified)

B. H. Thompson, Union Carbide Nuclear Co., Y-12 Plant, personal communication. From [SHAW]. 


\section{Distribution for ANL-00/25}

\section{Internal:}
S. B. Aase
A. M. Hermes
M. K. Richmann
D. P. Abraham
D. J. Hill
J. Sedlet
H. Arafat
J. J. Laidler (6)
W. Songakasiri
D. L. Bowers
R. A. Leonard
G. F. Vandegrift
C. Conner
E. F. Lewandowski
M. A. Williamson
R. E. Einziger
D. Lewis
J. L. Willit
J. R. Falkenberg
W. E. Miller
S. F. Wolf
P. J. Finck
L. Nunez
TIS Files
K. V. Gourishankar
M. C. Peter
D. J. Graziano
K. J. Quigley
J. E. Harmon
D. T. Reed

\section{External:}

DOE-OSTI (2)

ANL-E Library

ANL-W Library

Chemical Technology Division Review Committee Members:

H. U. Anderson, Emeritus, University of Missouri-Rolla, Rolla, MO

A. L. Bement, Jr., Purdue University, West Lafayette, IN

C. L. Hussey, University of Mississippi, University, MS

M. V. Koch, University of Washington, Seattle, WA

V. P. Roan, Jr., University of Florida, Palm Beach Gardens, FL

J. R. Selman, Illinois Institute of Technology, Chicago, IL

J. S. Tulenko, University of Florida, Gainsville, FL

E. D. Arthur, Los Alamos National Laboratory, Los Alamos, NM

M. Attrep, Jr., Los Alamos National Laboratory, Los Alamos, NM

D. Bennett, Los Alamos National Laboratory, Los Alamos, NM

J. C. Bresee, USDOE, Office of Civilian Radioactive Waste Management, Washington, DC

F. J. Goldner, U. S. Department of Energy, Germantown, MD

N. Haberman, USDOE, Washington, DC

T. Rudisill, Westinghouse, Aiken, SC

N. Schroeder, Los Alamos National Laboratory, Los Alamos, NM

K. Thomas, Los Alamos National Laboratory, Los Alamos, NM

M. Thompson, Westinghouse Savannah River Company, Aiken, SC

G. J. Van Tuyle, Los Alamos National Laboratory, Los Alamos, NM 